\title{
The Effect of Physical Exercise Toward the Memory Quality of Women
}

\author{
Ayla Maulida, Maruful Kahri, Tri Irianto \\ Department of Sport Education and Health \\ Lambung Mangkurat University \\ Banjarmasin, Indonesia \\ maulida.ayla@yahoo.com
}

\begin{abstract}
This research was intended to find out the quality and difference of the memory of women who actively exercise and the memory of women who do not actively exercise. The research method employed was ex post facto method. The population of this resaerch were 55 participants of two aerobic studios in Banjarbaru City. All of them were invited to participate in the preliminary study in the form of a fitness test aimed to determine those who fit to be the samples of group $A$, which consisted of women who actively exercised, and those who fit to be the samples of group B, which consisted of women who did not actively exercise. In the preliminary study, there were 44 people who were willing to participate, and after the test was conducted, 11 people were considered to meet the standard criteria to be samples of group A; thus, the number of samples in group $B$ was decided to be 11 as well. The sampling technique employed was purposive sampling. The data was analysed by using T-Test. The results of the research show that there was a difference in memory quality between women who actively exercised and women who did not actively exercise, consistent with the criteria of the test with to(calculated) value of $2,123>$ ttable $(20)=1.72$, and $p$-value of $0.046<0.05$. The mean of both groups was 0.727 . The memory of women who actively exercise is better than the memory of women who do not actively exercise. It can be concluded that physical exercise gives contribution to the improvement of memory quality of women.
\end{abstract}

Keywords: effect, exercise, memory, woman

\section{INTRODUCTION}

Every person wants a good quality of life. The quality of life itself can be measured by a variety of factors; one of the factors that can determine a person's quality of life is whether he/she has a fit body and good memory. People who have a good quality of life, are healthy people physically, spiritually and socially [1]. Although a good combination of physical and psychological is characterized by a good quality of memory, many people also assume that the quality of memory will decrease when entering old age, but frequently decline at a young age. There are many examples in daily life that show that even young people can show signs of weakening memory. Body health is very closely related to memory; physical activity carried out regularly will ultimately affect the quality of one's memory. Moderate and regular exercise can improve brain performance, when we move or exercise, oxygen intake to the brain is increasing [2].

In this regard, in modern times life patterns have begun to change, especially in career women or those who are married and have children under five, they are preoccupied with taking care of work, home and children, pampered with electronic devices that are practical and then start to be lazy to move, or do not have time to exercise which ultimately has an impact on the decline in the quality of physical fitness and the quality of memory. The strongest causes of memory decline are depression, lack of exercise and high blood pressure.

Forgetting is a problem commonly experienced by humans which is considered normal and has become a risk of our ability as humans who have the ability to remember. At the time of entering adulthood, it is said that women have better memory than men. Men activate the amygdala in the right side of their brain, women activate the left side [2]. Activation on the left brain will make people remember the details more and remember the point. However, the problem today is that there are many cases of "forgetting" in women which increases and even becomes fatal to life, from the category of simple forgetfulness such as forgetting to put something, conveying a message, even to forgetting the truth. The true fatal and dangerous effect caused is like forgetting to turn off the stove when traveling out of the house. We can see that age is not the only major factor that makes a person senile faster [3]. It is unfortunate indeed if life is adorned with the word forget, forgetting can be very annoying and disturbing when we are in need of important information while the memory is unable to bring it back. Even certain people forget that "forgetting" has become a kind of 'disease' from ordinary forgetfulness to forget too often [2]. From various articles that researchers have read, it is mentioned that health and regular physical activity can improve brain performance and sharpen memory, such as the statement that memory achievement is related to physical state[4]. Our mental and physical condition can also be a clue in recalling a thing because both conditions can trigger state-dependent memory (memories that depend on physical conditions) [5]. It is because of this inadequate physical condition that causes a decrease in memory (PDI) at an early age, and how this state-dependent memory will be used as an object in research. In an effort to solve the problem, the researcher conducted a series of studies to ascertain the extent to which regular physical activity can affect memory of women. The targets of this research were career women and housewives aged between 26-35 years who are still actively exercising regularly every week, for example, carrying out Zumba and Aerobic Gymnastics or other types of sports performed at sports training centers (sample A) and was compared to career women or housewives aged 26-35 years who are not active in sports (sample B / control group). In this study the researcher conducted a survey and data collection in advance of sample A by conducting a series of tests and filling in a number of data that ensures that sample $\mathrm{A}$ is actively 
endorphin hormone significantly into blood plasma.

exercising regularly and ensures that sample B is not actively doing routine exercise. The results of the memory record were applied to the subtest in the IST intelligence test (Intelligenz Structure Test) and measurements that have been determined as a measuring tool in the memory test which was carried out immediately after the data and samples were collected completely. Then, through these data and the results of measurement of memory statistical calculations were carried out to determine the impact of physical activity on memory and the results of the comparison of the quality of samples $\mathrm{A}$ and $\mathrm{B}$.

\section{METHODOLOGY}

The method used in this study is a comparative method. The comparative research method selected is ex post facto which means the data is collected after all the events collected have been completed". While operationally, the ex post facto method is a research method that examines cause and effect where it happens in the field without giving treatment to certain variables.

In this study, there were two sample groups that were examined; group A was a group of women who have been actively exercising on a daily basis such as aerobic or zumba gymnastics activities carried out at least $2 \mathrm{x}$ in a week, as well as having good physical fitness, and group B consisted of women who do not actively exercise which is called comparison group. Each group consisted of 11 women as the research sample. The tests used the Intelligenz Structure Test. The subtest used in this study is the 9th subtest with 20 items. The sub-test is sub-9, which is ME (Merkaufgaben) symbol training. This subtest measures memory, concentration that persists, and endurance. The data were analysed by t-test.

\section{RESUlTS AND DISCUSSION}

Based on the results of data collection and data analysis, it can be seen that there are differences in the quality of memory in women who actively exercise and women who do not actively exercise according to the testing criteria t0 (count) of $2,123>$ ttable $(20)=1.72$ with $p$ - value of $0.046<0.05$. The results of statistical calculations illustrate that there are indeed differences in memory in women who actively exercise and women who do not actively exercise

While maintaining one's cognitive function is inseparable from the endorphin hormone produced in the brain with higher amounts when the body is actively exercising. If enough endorphin hormone is released, the hippocampus as a brain center related to learning and memory will be activated. Thus, brain health can be maintained [6].

Indeed, researchers themselves do not know how certain or what percentage of endorphin hormones released during exercise can affect the strength of one's memory. According to an article that researcher has read that even a small supply of endorphin hormones in the body will have a good impact on brain function. Exercise above 30 minutes continuously will help release endorphin hormone. How the intensity of exercise will help the process of releasing endorphin hormones in the human body [7]: while much data has been published about the relationship between endorphins and intensity of exercise, other researchers tested different forms of exercise - mostly the difference between running and bicycling.

From the explanation above, it can be seen that biking or running to the limit of $60-70 \%$ VO2-max will release
Moreover, during exercise there will be an increase in pulse; the volume of blood flow carries more oxygen through the spinal cord to the brain so that it will facilitate the brain in reproducing new cells, not least the emergence of stimulation of the endocrine glands which will affect the increasing endorphin hormone production in the hippocampus. Endorphin hormones in the body play a role in repairing brain tissue and able to strengthen memory. They work as a reinforcing agent in the ability to remember, so that if this is stimulated or given a proper stimulus, it will activate the hippocampus function more optimally which is very useful for the formation of memory.

It can be understood that the body which is stimulated by actively exercising regularly with a certain intensity (mild and moderate) will stimulate the endocrine glands so that it can produce more endorphin hormones in the brain. Therefore, it will make the brain becomes more active and functional. Because people who are active in sports should have a fit body, they are expected to have good memory too. Basically, not only exercise can help release endorphin hormones in a person's body, so many factors can influence it. Endorphins are produced and released from the pituitary gland. They are released during continuing exercises, fear, love, music, chocolates eating, laughter, sex, orgasm etc. From these explanations, it can be seen that not only exercises affect the release of endorphin hormone in the brain, so many factors involved in it such as fear, love, music, eating chocolate, laughing, sex and orgasm that can also affect the release of endorphin hormones. Each individual has the ability and capacity in producing endorphin hormones. This capacity also depends on the habits of each individual, for example the supply of nutrients and good or bad habits that are often done. It does not rule out that people who actively exercise having bad habits such as smoking and irregular sleep patterns, and people who do not actively exercise even have healthy lifestyles and regular sleep and are always cheerful in their daily lives. This will also greatly affect the quality of the individual's memory. This can be seen in the results of studies that show that some women who do not actively exercise also have a good quality of memory.

Basically, a person's memory ability is actually influenced by many things, for example: age, gender, physical condition, emotions, food, interests and motivation. However, this study only examined the relationship between memory and one's activity in sports even though in a study carried out, it cannot be separated from various shortcomings and clear obstacles that will directly affect the results of this study. In fact, he results of statistical data obtained from this study indeed illustrate that there are differences in the quality of memory in women who actively exercise and women who do not actively exercise; women who actively exercise have better memory than women who do not actively exercise.

\section{CONCLUSION}

Based on the results of data analysis, the results of this study can be concluded as follows: "Women who actively exercise have a better quality of memory compared to women who do not actively exercise".

\section{ACKNOWLEDGMENT}

We would like to be grateful to the Dean of Teacher Training and Education Faculty, Lambung Mangkurat 
[3] Y. Turana, Stop Pikun di Usia Muda, Jakarta: PT. Gramedia ustaka

University, who has supported us in the form of funding. Therefore, we could join this International Conference.

\section{REFERENCES}

[1] M. Kahri, Pendidikan Jasmani Terhadap Kebugaran Jasmani, Boddy Mass Index (BMI), Antropometri, Motor Educability Kaitannya Dengan Perbedaan Lingkungan Sosial dan Geografis. Doctoral Dissertation, Universitas Pendidikan Indonesia, 2011.

[2] I. Palgunadi, Cara Sakti Bikin Otak dan Ingatanmu Secerdas Einsten dan Setajam Silet, Jakarta: Araska, 2014.
[4] A. Sujanto, Psikologi Umum, Jakarta: Bumi Aksara, 2001

[5] C. Wide and C. Tavris, Psikologi, Jakarta: Erlangga, 2007.

[6] S. Haruyama, The Miracle Of Endorphin - Gold Edition, Bandung: Mizan Media Utama, 2014.

[7] A. Leuenberger, Impluse: The Premier Journal for Undergraduate Publications in the Neurosciences. Lafayette College, 2006. 